\title{
Predicting drug metabolism-dependent toxicity
}

\author{
Hermann M. Bolt $\cdot$ Jan G. Hengstler
}

Published online: 23 June 2009

(c) Springer-Verlag 2009

In recent years, endogenous and xenobiotic metabolism has been one of the cutting edge topics of our journal (Hengstler and Bolt 2008; Bolt and Hengstler 2007, 2008a, b). Because of the dynamic progress in the field of drug metabolizing enzymes, we have initiated a new series of review articles that focus on nomenclature, substrate specificities, genetic organization, polymorphisms, clinical relevance and role in carcinogenesis (Pelkonen et al. 2008; Lankisch et al. 2008; Strassburg et al. 2008; Decker et al. 2009; Adam and Laufs 2008; Macdonald and Gledhill 2007). In order to give our readers a better overview over the numerous articles published in the field of drug metabolism in our journal during the past 2 years, we summarize their key messages and link them to the respective articles (Table 1).

Table 1 Take home messages of recent metabolism related publications in the Archives of Toxicology

\begin{tabular}{ll}
\hline Key message & Reference \\
\hline $\begin{array}{l}\text { Low doses of the organochlorine } \\
\text { pesticide methoxychlor reduce }\end{array}$ & Vaithinathan et al. (2008) \\
activities of steroidogenic & \\
enzymes & \\
The expression of CYP and GST & Rudolf et al. (2008) \\
isoforms is strongly influenced by & \\
diet in rats and mice (amino acid & \\
based vs. egg-white diet, vs. & \\
standard laboratory chow) & \\
\hline
\end{tabular}

H. M. Bolt · J. G. Hengstler ( $\square)$

Leibniz Research Centre for Working Environment and Human Factors (IfADo), TU Dortmund, Ardeystraße 67,

44139 Dortmund, Germany

e-mail: hengstler@ifado.de
Table 1 continued

\begin{tabular}{ll}
\hline Key message & Reference \\
\hline The authors performed a systematic & Westerink et al. (2008) \\
study with a set of 119 compounds & \\
comparing CYP1A1/1A2 & \\
induction and competition in rat & \\
and human cells; several so far & \\
unknown interspecies differences & \\
were identified & \\
Test compound-induced gene & Schug et al. (2008) \\
expression patterns are similar in & \\
liver in vivo and in hepatocytes in & \\
vitro if optimized culture & \\
conditions are applied & \\
Potassium dichromate inhibits brush & Arivarasu et al. (2008) \\
border enzymes of the intestine & \\
and causes lipid peroxidation & \\
Non-alcoholic steatohepatitis & Fisher et al. (2008) \\
$\begin{array}{l}\text { (NASH) leads to increased PXR, } \\
\text { Nqo1 and CYP4A14 expression }\end{array}$ & \\
Some aromatic amines increase the & Borza et al. (2008) \\
influence of benzo[a]pyrene on Ah & \\
receptor dependent genes & \\
CYP2E1 mediates the formation of & Settels et al. 2008) \\
glycidamide, the ultimate & \\
carcinogenic metabolite of & \\
acrylamide & \\
Amitraz, a widely used formamidine & Chou et al. (2008) \\
pesticide, induces hepatic estrogen & \\
and testosterone metabolism & \\
Heavy metal exposure (cadmium, & Glahn et al. (2008) \\
cobalt and lead) of bronchial \\
epithelial cells leads to \\
upregulation of steroid \\
metabolism \\
$\begin{array}{l}\text { Chronic exposure to low doses of } \\
\text { and adrenal steroid metabolism }\end{array}$ \\
\hline
\end{tabular}


Table 1 continued

\begin{tabular}{|c|c|}
\hline Key message & Reference \\
\hline $\begin{array}{l}\text { This bio-distribution study of the } \\
\text { neurotoxic substance } 1,2- \\
\text { diethylbenzene shows that the } \\
\text { parent compound and its } \\
\text { metabolite } 1-\left(2^{\prime} \text {-ethylphenyl) }\right. \\
\text { ethanol is found at higher } \\
\text { concentrations in the brain than in } \\
\text { the blood of rats }\end{array}$ & Payan et al. 2008) \\
\hline $\begin{array}{l}\text { A polymorphism of the microsomal } \\
\text { epoxide hydrolase gene (exon } 3 \\
\text { His genotype) is associated with } \\
\text { urinary bladder cancer risk }\end{array}$ & Srivastava et al. (2008) \\
\hline $\begin{array}{l}\text { This review summarizes the state of } \\
\text { the art concerning alternative } \\
\text { methods to animal experiments } \\
\text { including in vitro systems for } \\
\text { metabolism }\end{array}$ & Lilienblum et al. (2008) \\
\hline $\begin{array}{l}\text { This study demonstrates large } \\
\text { interspecies differences in } \\
\text { CYP11B1-dependent } \\
\text { bioactivation of the adrenocortical } \\
\text { toxicant 3-methylsulphonyl-DDE. } \\
\text { Bioactivation is high in adrenal } \\
\text { tissue of hamsters and mice in } \\
\text { contrast to guinea pigs and rats }\end{array}$ & Lindstrom et al. (2008) \\
\hline $\begin{array}{l}\text { Gene expression profiling of cultured } \\
\text { human hepatocytes to Aroclor } \\
1254 \text { reveals a strong response of } \\
\text { genes involved in xenobiotic } \\
\text { defence }\end{array}$ & Thum and Borlak (2008) \\
\hline $\begin{array}{l}\text { This study systematically evaluates } \\
\text { the metabolism of } N \text {-methyl- } N \text { - } \\
\text { 2,4,6-tetranitroaniline (tetryl) in } \\
\text { rats }\end{array}$ & Myers and Spinnato (2007) \\
\hline $\begin{array}{l}\text { The insecticide profenofos induces } \\
\text { genes related to steroidogenesis in } \\
\text { rat testes, including CYP17A1, } \\
\text { CYP11A1 and steroidogenic acute } \\
\text { regulatory protein (StAR). The } \\
\text { latter genes are suggested as new } \\
\text { biomarkers of testicular toxicity }\end{array}$ & Moustafa et al. (2007) \\
\hline $\begin{array}{l}\text { CYP2C29 represents a novel } \\
\text { hepatotoxicity biomarker }\end{array}$ & Spicker et al. (2007) \\
\hline $\begin{array}{l}\text { Histamine increases activity and } \\
\text { protein levels of CYP1A1 and } \\
\text { CYP2E1 in vivo, illustrating a role } \\
\text { of CYPs in inflammation }\end{array}$ & Davila-Borja et al. (2007) \\
\hline $\begin{array}{l}\text { Genotype frequencies of } \\
\text { CYP2E1*7B are similar in } \\
\text { Turkish compared to other } \\
\text { Caucasian populations }\end{array}$ & Ulusoy et al. (2007) \\
\hline $\begin{array}{l}\text { Microsomal epoxide hydrolase } \\
\text { (EPHX1) is not significantly } \\
\text { associated with risk of myocardial } \\
\text { infarction }\end{array}$ & Cornelis et al. (2007) \\
\hline
\end{tabular}

Table 1 continued

\begin{tabular}{ll}
\hline Key message & Reference \\
\hline Increased total levels of glutathione & Parody et al. (2007) \\
and decreased expression of & \\
multidrug-resistance protein2 & \\
(Mrp2) are involved in resistance & \\
of hepatocytes to ethacrynic acid & \\
toxicity & \\
Gene expression profiling in lung & Sul et al. (2007) \\
tissues of rats exposed to 5 and & \\
10 ppm formaldehyde identifies & \\
expression alterations of & \\
cytochrome P450 isoenzymes & \\
Dehydrotarplatin, a new & \\
antineoplastic drug, causes a & \\
feminization of the pattern of CYP & \\
enzymes in male rat liver & \\
UGT1A9 is a key enzyme catalyzing & Uesawa et al. (2007) \\
the glucuronidation of dulcin. & \\
Dulcin, now banned, was a widely & \\
used sweetener & \\
This study presents a systematic & Elovaara et al. (2007) \\
comparison of CYP-induction in & \\
lung and liver & \\
This study systematically compares & Skupinska et al. (2007) \\
CYP1A induction by PAHs in the & \\
hepatoma cell line HepG2 and in \\
the breast cancer cell line MCF-7 & \\
Di (2-ethylhexyl) phthalate (DEHP) & Ito et al. (2007) \\
induces PPAR alpha in mice and & \\
rats but not in marmosets & \\
This article presents a PBPK model & Lee et al. (2007) \\
describing lactational transfer of & \\
PCB 153 & \\
Cigarette smoking increases & \\
urothelial cells & \\
\hline
\end{tabular}

\section{References}

Adam O, Laufs U (2008) Antioxidative effects of statins. Arch Toxicol 82:885-892

Arivarasu NA, Fatima S, Mahmood R (2008) Oral administration of potassium dichromate inhibits brush border membrane enzymes and alters anti-oxidant status of rat intestine. Arch Toxicol 82:951-958

Bolt HM, Hengstler JG (2007) The past an the future of toxicology. Arch Toxicol 81:1-3

Bolt HM, Hengstler JG (2008a) A new series of review artiles on drug metabolizing enzymes: nomenclature of isoenzyme families, genetic organization, polymorphisms, substrate specificities, clinical relevance and role in carcinogenesis. Arch Toxicol 82:413-414

Bolt HM, Hengstler JG (2008b) Most cited articles in the Archives of Toxicology: the debate about possibilities and limitations of in vitro toxicity tests and replacement of in vivo studies. Arch Toxicol 82:881-883 
Borza A, Plottner S, Wolf A, Behm C, Selinski S, Hengstler JG, Roos PH, Bolt HM, Kuhlmann J, Follmann W (2008) Synergism of aromatic amines and benzo[a]pyrene in induction of $\mathrm{Ah}$ receptor-dependent genes. Arch Toxicol 82:973-980

Chou CP, Lu SY, Ueng TH (2008) Modulation of serum concentrations and hepatic metabolism of $17 \beta$-estradiol and testosterone by amitraz in rats. Arch Toxicol 82:729-737

Cornelis MC, El-Sohemy A, Campos H (2007) Microsomal epoxide hydrolase genotype and risk of myocardial infarction. Arch Toxicol 81:641-645

Davila-Borja VM, Belmont JA, Espinosa JJ, Moreno-Sanchez R, Albores A, Montero RD (2007) Induction of CYP1A1 and CYP2E1 in rat liver by histamine: binding and kinetic studies. Arch Toxicol 81:697-709

Decker M, Arand M, Cronin A (2009) Mammalian epoxide hydrolases in xenobiotic metabolism and signalling. Arch Toxicol 83:297-318

Dorrenhaus A, Muller T, Roos PH (2007) Increased CYP1A1 expression in human exfoliated urothelial cells of cigarette smokers compared to non-smokers. Arch Toxicol 81:19-25

Elovaara E, Mikkola J, Stockmann-Juvala H, Luukkanen L, KeskiHynnila H, Kostiainen R, Pasanen M, Pelkonen O, Vainio H (2007) Polycyclic aromatic hydrocarbon (PAH) metabolizing enzyme activities in human lung, and their inducibility by exposure to naphthalene, phenanthrene, pyrene, chrysene, and benzo $(a)$ pyrene as shown in the rat lung and liver. Arch Toxicol 81:169-182

Fisher CD, Jackson JP, Lickteig AJ, Augustine LM, Cherrington NJ (2008) Drug metabolizing enzyme induction pathways in experimental non-alcoholic steatohepatitis. Arch Toxicol 82:959-964

Glahn F, Schmidt-Heck W, Zellmer S, Guthke R, Wiese J, Golka K, Hergenroder R, Degen GH, Lehmann T, Hermes M, Schormann W, Brulport M, Bauer A, Bedawy E, Gebhardt R, Hengstler JG, Foth H (2008) Cadmium, cobalt and lead cause stress response, cell cycle deregulation and increased steroid as well as xenobiotic metabolism in primary normal human bronchial epithelial cells which is coordinated by at least nine transcription factors. Arch Toxicol 82:513-524

Grignard E, Gueguen Y, Grison S, Lobaccaro JMA, Gourmelon P, Souidi M (2008) In vivo effects of chronic contamination with 137 cesium on testicular and adrenal steroidogenesis. Arch Toxicol 82:583-589

Hengstler JG, Bolt HM (2008) Failure in drug development: the role of inhibition and induction of cytochrome P450 enzymes. Arch Toxicol 82:665-666

Ito Y, Yamanoshita O, Kurata Y, Kamijima M, Aoyama T, Nakajima $\mathrm{T}$ (2007) Induction of peroxisome proliferator-activated receptor alpha $(\operatorname{PPAR} \alpha)$-related enzymes by di(2-ethylhexyl) phthalate (DEHP) treatment in mice and rats, but not marmosets. Arch Toxicol 81:219-226

Lankisch TO, Gillman TC, Erichsen TJ, Ehmer U, Kalthoff S, Freiberg N, Munzel PA, Manns MP, Strassburg CP (2008) Aryl hydrocarbon receptor-mediated regulation of the human estrogen and bile acid UDP-glucuronosyltransferase 1A3 gene. Arch Toxicol 82:573-582

Lee SK, Ou YC, Andersen ME, Yang RSH (2007) A physiologically based pharmacokinetic model for lactational transfer of PCB 153 with or without PCB 126 in mice. Arch Toxicol 81:101-111

Lilienblum W, Dekant W, Foth H, Gebel T, Hengstler JG, Kahl R, Kramer PJ, Schweinfurth H, Wollin KM (2008) Alternative methods to safety studies in experimental animals: role in the risk assessment of chemicals under the new European Chemicals Legislation (REACH). Arch Toxicol 82:211-236
Lindstrom V, Brandt I, Lindhe O (2008) Species differences in 3-methylsulphonyl-DDE bioactivation by adrenocortical tissue. Arch Toxicol 82:159-163

Macdonald N, Gledhill A (2007) Potential impact of ABCB1 (p-glycoprotein) polymorphisms on avermectin toxicity in humans. Arch Toxicol 81:553-563

Moustafa GG, Ibrahim ZS, Hashimoto Y, Alkelch AM, Sakamoto KQ, Ishizuka M, Fujita S (2007) Testicular toxicity of profenofos in matured male rats. Arch Toxicol 81:875-881

Myers SR, Spinnato JA (2007) Tissue distribution and elimination of $N$-methyl- $N$-2,4,6-tetranitroaniline (tetryl) in rats. Arch Toxicol 81:841-848

Nannelli A, Messina A, Marini S, Trasciatti S, Longo V, Gervasi PG (2007) Effects of the anticancer dehydrotarplatin on cytochrome P450 and antioxidant enzymes in male rat tissues. Arch Toxicol 81:479-487

Parody JP, Alvarez MD, Quiroga A, Ronco MT, Francess D, Carnovale C, Carrillo MC (2007) Hepatocytes isolated from preneoplastic rat livers are resistant to ethacrynic acid cytotoxicity. Arch Toxicol 81:565-573

Payan JP, Binet S, Beydon D, Ferrari E (2008) Bio-distribution study of 1,2-diethylbenzene and its main metabolites by whole-body autoradiography and tissue homogenates. Arch Toxicol 82:591600

Pelkonen O, Turpeinen M, Hakkola J, Honkakoski P, Hukkanen J, Raunio H (2008) Inhibition and induction of human cytochrome P450 enzymes: current status. Arch Toxicol 82:667-715

Rudolf JL, Bauerly KA, Tchaparian E, Rucker RB, Mitchell AE (2008) The influence of diet composition on phase I and II biotransformation enzyme induction. Arch Toxicol 82:893-901

Schug M, Heise T, Bauer A, Storm D, Blaszkewicz M, Bedawy E, Brulport M, Geppert B, Hermes M, Föllmann W, Rapp K, Maccoux L, Schormann W, Appel KE, Oberemm A, GundertRemy U, Hengstler JG (2008) Primary rat hepatocytes as in vitro system for gene expression studies: comparison of sandwich, Matrigel and 2D cultures. Arch Toxicol 82:923-931

Settels E, Bernauer U, Palavinskas R, Klaffke HS, Gundert-Remy U, Appel KE (2008) Human CYP2E1 mediates the formation of glycidamide from acrylamide. Arch Toxicol 82:717-727

Skupinska K, Misiewicz I, Kasprzycka-Guttman T (2007) A comparison of the concentration-effect relationships of PAHs on CYP1A induction in HepG2 and Mcf7 cells. Arch Toxicol 81:183-200

Spicker JS, Pedersen HT, Nielsen HB, Brunak S (2007) Analysis of cell death inducing compounds. Arch Toxicol 81:803-811

Srivastava DS, Mandhani A, Mittal RD (2008) Genetic polymorphisms of cytochrome P450 CYP1A1 (*2A) and microsomal epoxide hydrolase gene, interactions with tobacco-users, and susceptibility to bladder cancer: a study from North India. Arch Toxicol 82:633-639

Strassburg CP, Lankisch TO, Manns MP, Ehmer U (2008) Family 1 uridine- $5^{\prime}$-diphosphate glucuronosyltransferases (UGT1A): from Gilbert's syndrome to genetic organization and variability. Arch Toxicol 82:415-433

Sul D, Kim H, Oh E, Phark S, Cho E, Choi S, Kang HS, Kim EM, Hwang KW, Jung WW (2007) Gene expression profiling in lung tissues from rats exposed to formaldehyde. Arch Toxicol 81:589-597

Thum T, Borlak J (2008) Detection of early signals of hepatotoxicity by gene expression profiling studies with cultures of metabolically competent human hepatocytes. Arch Toxicol 82:89-101

Uesawa Y, Staines AG, Lockley D, Mohri K, Burchell B (2007) Identification of the human liver UDP-glucuronosyltransferase involved in the metabolism of $p$-ethoxyphenylurea (dulcin). Arch Toxicol 81:163-168 
Ulusoy G, Arinc E, Adali O (2007) Genotype and allele frequencies of polymorphic $C Y P 2 E 1$ in the Turkish population. Arch Toxicol 81:711-718

Vaithinathan S, Saradha B, Mathur PP (2008) Transient inhibitory effect of methoxychlor on testicular steroidogenesis in rat: an in vivo study. Arch Toxicol 82:833-839
Westerink WMA, Stevenson JCR, Schoonen WGEJ (2008) Pharmacologic profiling of human and rat cytochrome P450 1A1 and 1A2 induction and competition. Arch Toxicol 82:909921 